\title{
On the Connection Fibers of the Torus Longitudinalis in the Teleostean Brains*
}

\author{
By \\ Yashiki, K., Mishima, K., Hasegawa, T. and Ikuta, Y. \\ Department of Anatomy, Hiroshima University School of Medicine, Kure \\ (Director: Prof. N. Suzuki) \\ With 11 figures
}

\section{Introduction}

The torus longitudinalis is a characteristic brain part which is present only in teleosts and certain ganoids, such as Leptosteus, Amia and Polydon (Kudo, '23, p. 359). This part has been suggested by Kudo that it may play a part of the static function of the midbrain roof. The connection fibers of the torus are generally classified into two systems of afferent and efferent. The former is composed of afferent fibers from the.lamina commissuralis tecti and the tractus tecto-cerebellaris and the latter from the fibers of the tractus torotectalis. The other connection of the torus with the nucleus praetectalis, however, is not ascertained. Kudo ('23) has accurately studied on the same subject with Weigert-Pal and Pal-carmin preparations in teleosts and selachia but there are still remained some questions to be clarified.

\section{Material and Methods}

For this purpose, several specimens of teleosts which have welldeveloped torus longitudinalis were selected, for example Pagrosomus major, Mugil cephalus, Epinephelus akaara, Oncorhynchus tschawyscha,

*) This investigation was supported in part by a grant for scientific research from the Department of Educațion of the Japanese Government,

$-\mathrm{N}$, Suzuki- 
Sebastodes tolionis, Acheilognathus moriokae and Hapalogenys mucronatus. These brains were cut frontally, sagittally and horizontally in serial sections (ca. $15 \mu$ in thickness) after completely fixed with 20\% neutral formalin. These preparations were treated with Palcarmine, Weigert-Pal deying, Sugamo's method and Bielschowsky's silver impregnation.

\section{Description}

The torus longitudinalis is a convexed and longitudinally elongated body lying directly underneath the median part of the tectum. Its rostral part which fused with the commissura posterior is, as a whole, well developed and the other portion elongates caudalward and contacts with the dorsal sphere of the valvula cerebelli having a narrow space between them (Fig. 1). The fusion part of the torus longitudinalis and the commissura posterior is not always well-developed, for example Anguilla japonica, Neoperis sexfasciata and others, contrary to the description of Kudo ('23) $)^{1}$. Furthermore, the size of the torus is different in various species and in fact it depends upon the development of the tectum opticum (Franz, '11) or it may be parallel with the thickness of the molecular layer of the tectum (Kudo '23)2. But in spite of these observations it may not always accord with our specimens.

1. The afferent fibers of the torus longitudinalis.

The afferent connections of the torus are generally consisted of medullated fibers from the lamina commissuralis tecti and also from the tractus tecto-cerebellaris. In some fishes (Monopterus, van der Horst, '17) the tori of the two sides are connected by a commissure, commissura tegmentalis posterior. In several teleosts, moreover, Ku do ('23) found an intratoral connection passing through not only the commissura posterior but also the lamina commissuralis tecti (comp. Ariëns Kappers, Huber and Crosby, '36, p. 915). In Mugil cephalus, the intratoral connection fibers traverse the dorso-median niveau

1) Cf. Kudo ('23). Zur Erklärung der Frage, weshalb er im allgemeinen an seiner Verwachsungsstelle mit der Commisura posterior am dicksten ist. Diese Tatsache dürfte bedingt sein durch die zerebellotoralen Fasern, welche gerade und dieser Stelle in den Torus eintreten (p. 360).

2) Cf. Kudo ('23). Nach meinen Erfahrungen geht die Starke der Torus longitudinalis immer der Dicke der Molekularschicht des Tektum parallel. 
of the torus longitudinalis (Fig. 2). In our specimens, the fibers from the tractus tecto-cerebellaris take two pathways, so that one part of them ascends medio-dorsally to enter the torus of the same side and the others elongate further medially to entrance the contralateral side of the torus after crossed the median line of the torus longitudinalis (Figs. 3, 4). After entered the torus, most of them ascend dorsally and decussate with the contralateral fiber component at the midline of the torus. They make a thick fiber complex with the unmedullated fibers of the tractus toro-tectalis of $\mathrm{Ku}$ do at the dorso-median part of the torus longitudinalis (for example Mugil cephalus). In Hapalogenys mucronatus, however, the fibers from the tractus tectocerebellaris generally ascend dorsally after they entered the torus of the same side. They have no complex in the torus as indicated in Mugil cephalus, but they decussate only with the contralateral com. ponent in the bottom of the median part of the torus.

In Hapalogenys mucronatus, a few of the fibers from the commissura posterior separately entrance the ventro-median decussation of the torus, so that it is questionable that the other fiber connection with the nucleus praetectalis may be present as suggested by Kudo ('23). At the rostral part of the torus longitudinalis, the fibers of the lamina commissuralis tecti are transversally present (Fig. 5). In this section, the tori of two sides are separated in the median line and the entire body is surrounded with the ascending fibers of the tractus tecto-cerebellaris. The fibers of the lamina commissuralis tecti is consisted of the fibers from the tectum and most of them cross the dorso-medial part of the -torus. A few of these fibers terminate in the torus longitudinalis itself. Directly under this comissure, fine and slender commissure, intratoral commissure can be detected in the horizontal series of Mugil cephalus (Fig. 6 and comp. Fig. 2).

\section{The efferent fibers of the torus longitudinalis.}

The efferent fibers of the torus are consisted of the unmedullated toro-tectal fibers as already shown by Ariëns Kappers ('21) and Kudo ('23) in teleosts. These fibers are separated by the medullated fibers of the commissura intertectalis at the dorso-median area of the torus longitudinalis and moreover some of these unmedullated fibers perform a complex with the medullated afferent fibers which entered the median part of the torus (Fig. 7). The unmedullated fibers of the tractus toro-tectalis perform a kind of special structure, so that 
the naked neuraxes ${ }^{1)}$ are surrounded by the fine medullated fibers from the commissura intertectalis. It is a characteristic feature in teleosts as indicated by Ariëns Kappers and Kudo. Such a performation is also detected by the fiber bundle of the fasciculus retroflexus in teleosts, for example Mugil cephalus (Fig. 8). These fibers radiate into the tectum passing through the tectum to attain the molecular layer of the tectum and then elongate laterally (Fig. 9). In sagittal series, these gelatinous fibers (C. L. Herrick) from the dorso-median part of the whole length of the torus ascend dorsally into the tectum and pierce the tectum to elongate the surface layer of the tectum (Fig. 10): The termination of these fibers, however, cannot be traced, contrary to the description of Kudo ('23, p. 366 $)^{2}$. And in the sagittal series of Bielschowsky's silver impregnation, these gelatinous fibers also take the same courth of the above-mentioned specimens (Fig. 8 and Fig. 11) being accompanied by the fine medullated fibers until they attain the molecular layer of the tectum opticum.

\section{Concluding Remarks}

The afferent and efferent connective fibers of the torus longitudinalis were analysed in several teleostean brains. These serial preparations have been treated with various neuro-histological techniques, such as Weigert-Pal, Pal-carmine deying, Sugamo's method and Bielschowsky's silver impregnation.

The torus longitudinalis is only present in teleosts and some ganolds, and lies underneath the tectum opticum. Its rostral segment is fused with the commissura posterior and the other part elongate caudalward along the median zone of the tectum. The caudal seg. ment of the torus lies on the frontal part of the valvula cerebelli. The fusion point of the torus is, as a whole, mostly developed and caudalward it is gradually reduced in its size. The developmental

1) Cf. Ariëns Kappers, Huber and Grosby ('36, p. 897). This relation is often found where myelinated fibers join unmyelinated fibers; thus it has been found in the habenulo-peduncular tract (Ariëns Kappers) and in the torotectal fibers of teleosts (Kudo), which are surrounded by the medullated fibers of the lamina commissuralis tecti.

2) Cf. Kudo ('23, p. 366). Die Bündel treten nämlich aus dem frontalen Abschnitt des Torus longitudinalis ventro-frontalwärts direkt in das Bett der commissura posterior, verlaufen dann durch die Opticusfaserung (die dorsale Opticuswurzel) latero-ventrofrontalwärts, erreichen lateral vom Genikulatum die Molekularschicht des ventralsten Tektumteils und strahlen in dieselbe ein. 
degree of the torus longitudinalis is not always parallel with that of the molecular layer of the tectum.

The afferent fibers are consisted of the fibers from the lamina commissuralis tecti, tractus tecto-cerebellaris and the commissura posterior. Among the fibers from the tractus tecto-cerebellaris, most of them enter the torus of the same side and the others cross the ventromedian line of the torus longitudinalis to enter the contralateral part of the torus (for example Oncorhynchus tschawyscha). The afferent fibers which ascend dorsally after entered the torus make a fiber complex with the unmedullated fibers of the tractus toro-tectalis at the dorso-median part (for example Mugil cephalus). Besides, the medullated fibers of the commissura intratoralis which connect the tori of the two sides can be detected in Mugil cephalus. The connection fibers of the torus longitudinalis and the nucleus praetectalis, however, cannot be ascertained in our preparations.

The afferent fibers of the tractus toro-tectalis is composed of the special naked neuraxes which are similar with the fiber bundle of the fasciculus retroflexus, as described by Ariëns Kappers and Kudo in teleosts. These fibers chiefly arise from the dorso-median area of the torus longitudinalis and are separately surrounded with the fine medullated fibers of the commissura intertectalis. They ascend in rapid succession to enter the tectum passing through its whole thickness to reach the molecular layer of the tectum opticum, but its termination is uncertain.

\section{References}

Ariëns Kappers, C.U. 1921 Die vergleichende Anatomie des Nervensystems der Wirbeltiere und des Menschen. 2 Bd. Haarlem.

Ariëns Kappers, C.U. Huber, G.C. and Crosby, E.C. 1936 The comparative anatomy of the nervous system of vertebrates, including man. 2 Vols. New York, The Macmillan Company.

Franz, V. 1911 Das Kleinhirn der Knochenfische. Zool. Jahrb. Bd. 32.

Goldstein, K. 1904 Untersuchungen über das Vorderhirn und Zwischenhirn einiger Knochenfische, nebst einiger Beitrage über Mittelhirn und Kleinhirn derselben. Arch. f. Mikr. Anat., Bd. 66.

Kashiwamura, T. 1955 Contributions to the comparative anatomy of the tractus tecto-cerebellaris in the brains of some vertebrates. Hiroshima J. Med. Sci., vol. 3 , no. $3 / 4$.

Kudo, K. 1923 Über den Torus longitudinalis der Knochenfische. Anat. Anz., Bd. 52, Nr. 15/16.

$\mathrm{Oki}, \mathrm{H} .1955$ On the commissura transversa of Haller and its interrelating fiber sys- 
tems in the teleostean brains. Hiroshima J. Med. Sci., vol. 4, no. 2/3.

Suzuki, N. 1928 Contributions to the theory of teratogeny based on the microscopic investigation of the central nervous system of single and double monsters of dogsalmon-embryos (Oncorhynchus keta Walbaum). Arb. a. d. Anat. Inst. Kaiserl.-Jap. Univ, zu Sendai, Heft, XIII.

\section{Abbreviation for all figures}

aff. $f$ afferent fibers

com. int. $t$ commissura intertectalis

com. int. tor. commissura intratoralis

com. p... conmissura posterior

com. teg. commissura tegmentalis posterior

f. compl. fiber complex

fasc. retrofi fasciculus retroflexus

lam. com. lamina commissuralis tecti

med. t. tong. median tectum tongue

mol. 1 . molecular layer

med. f. of lam. com. $t$. medullated fibers of lamina commissuralis tecti t........ tectum opticum'

tor. longt. torus longitudinalis tr. t. cb. tractus tecto-cerebellaris tr. tor. $t$ tractus toro-tectalis unmed. f. of tr. tor. $t$ unmedullated fibers of tractus toro-tectalis valv. cb. valvula cerebelli 
Plate I

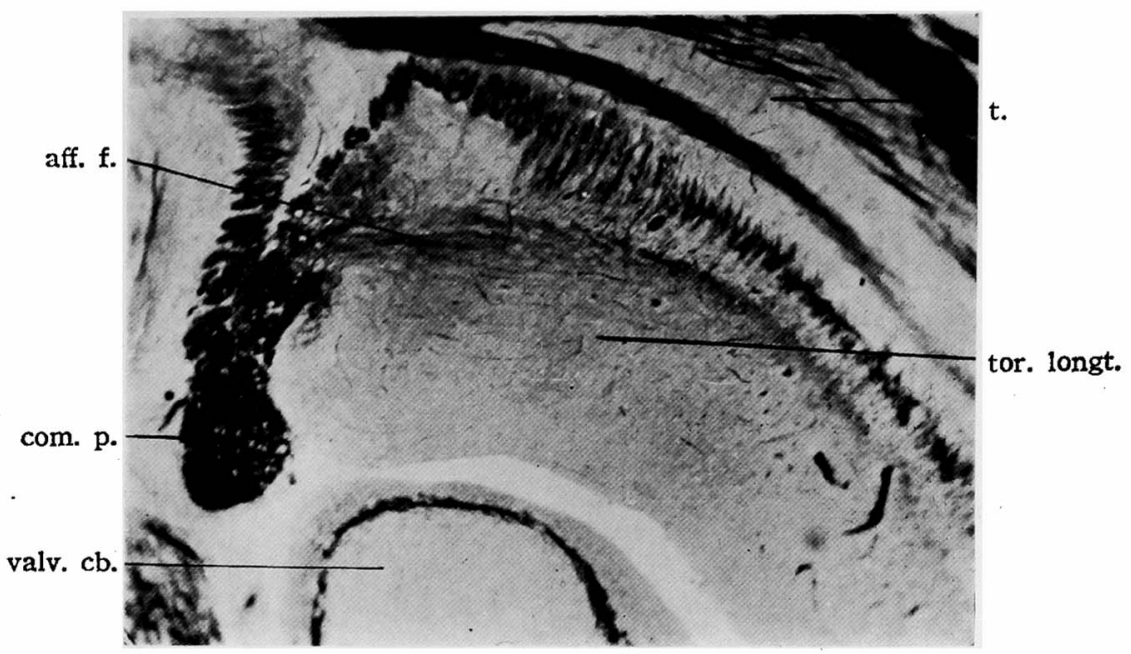

Fig. 1. Sagittal section cutting through the fusion segment of the torus longitudinalis and the commissura posterior in the brain of Mugil cephalus.

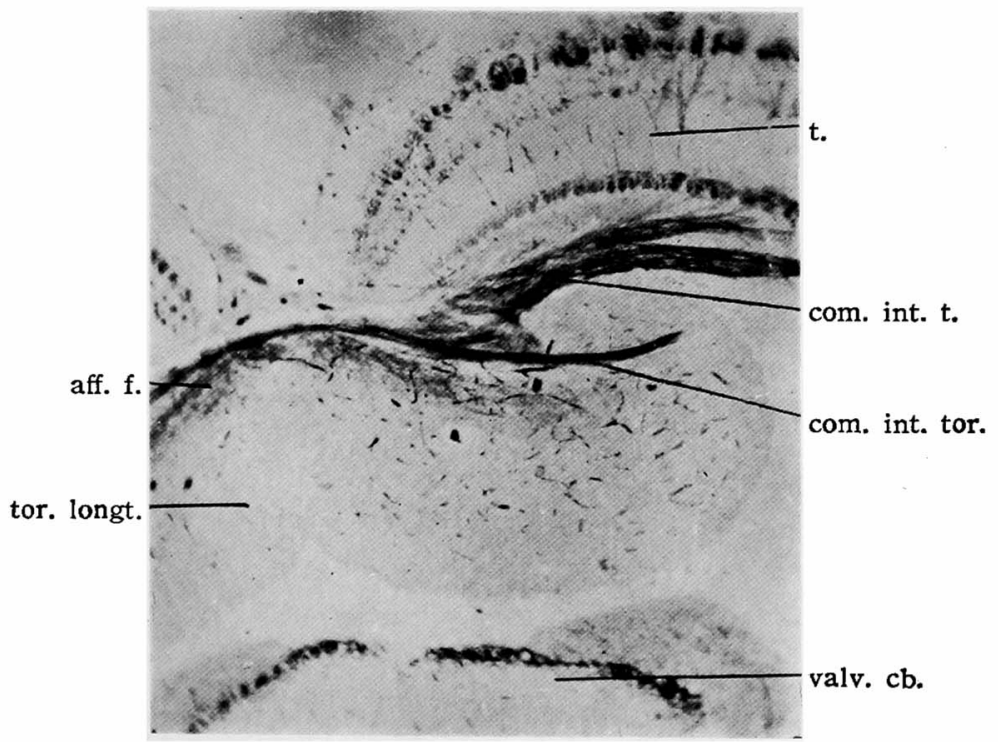

Fig. 2. Transverse section cutting through the middle segment of the torus longitudinalis in the brain of Mugil cephalus.

K. Yashiki, K. Mishima, T. Hasegawa, and Y. Ikuta. 


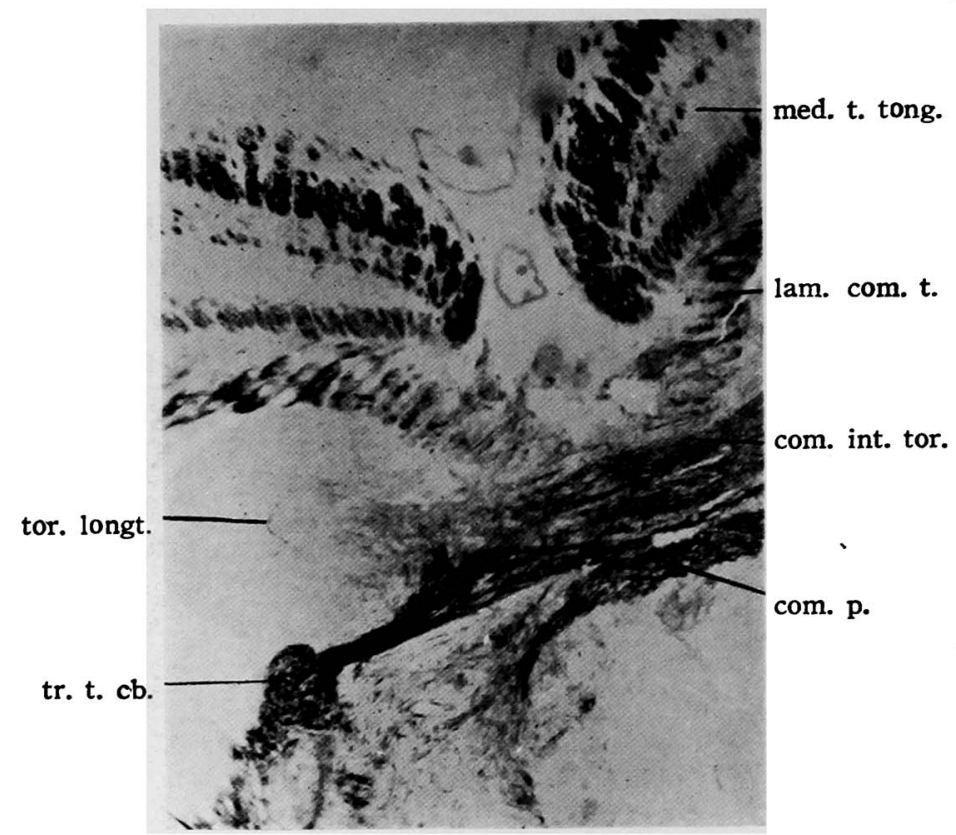

Fig. 3. Transverse section cutting through the commissura posterior in the brain of Hapalogenys mucronatus.

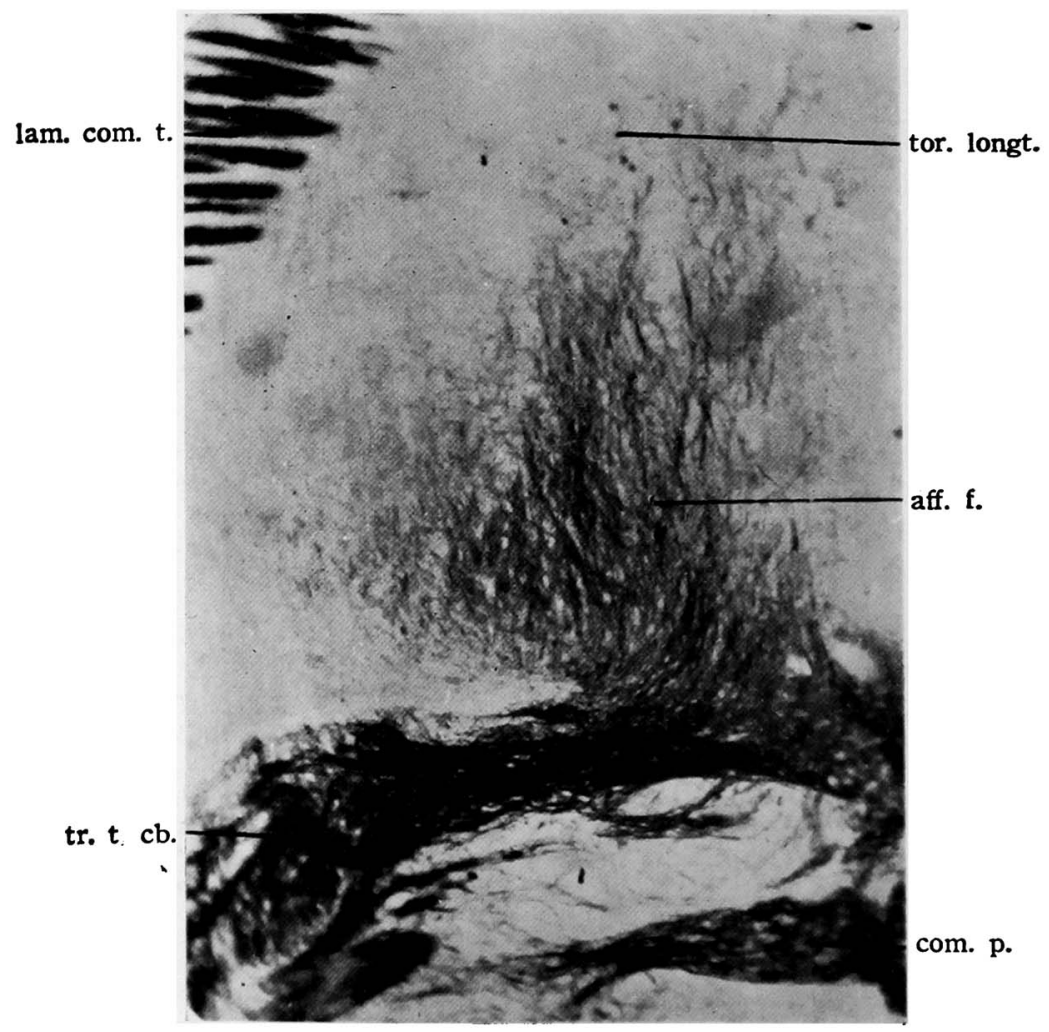

Fig. 4. Transverse section cutting thraugh the commissura posterior in the brain of Hapalogenys mucronatus. 
Plate III

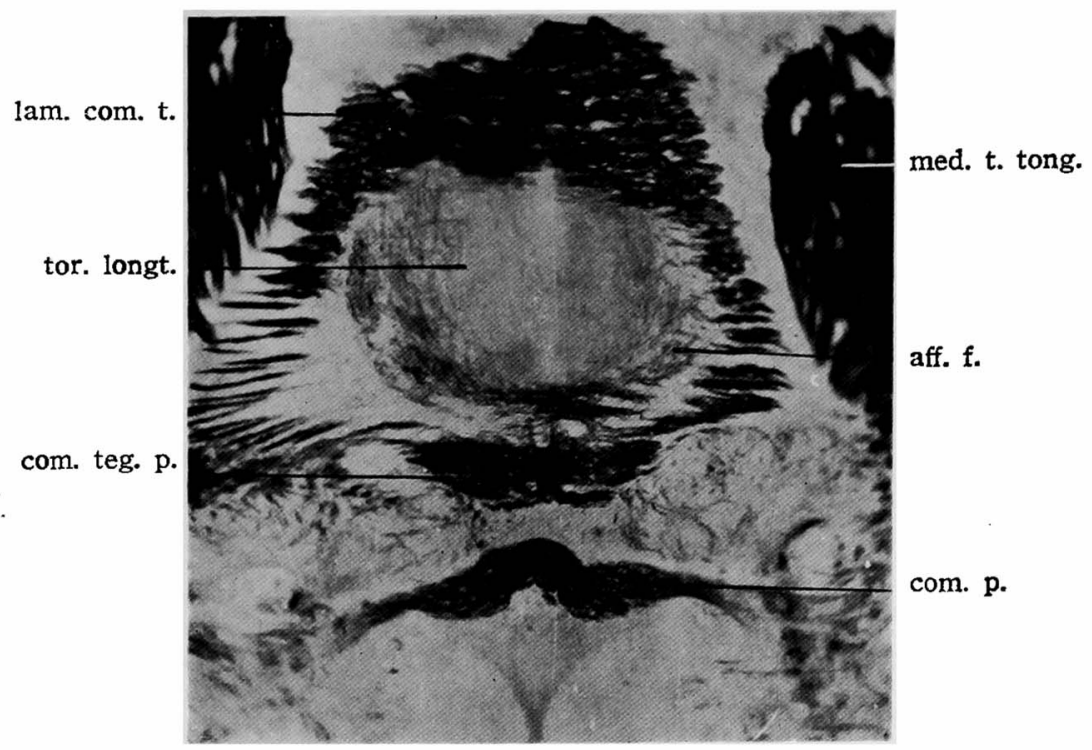

Fig. 5. Transverse section cutting through the rostral segment of the torus longitudinalis in the brain of Hapalogenys mucronatus.

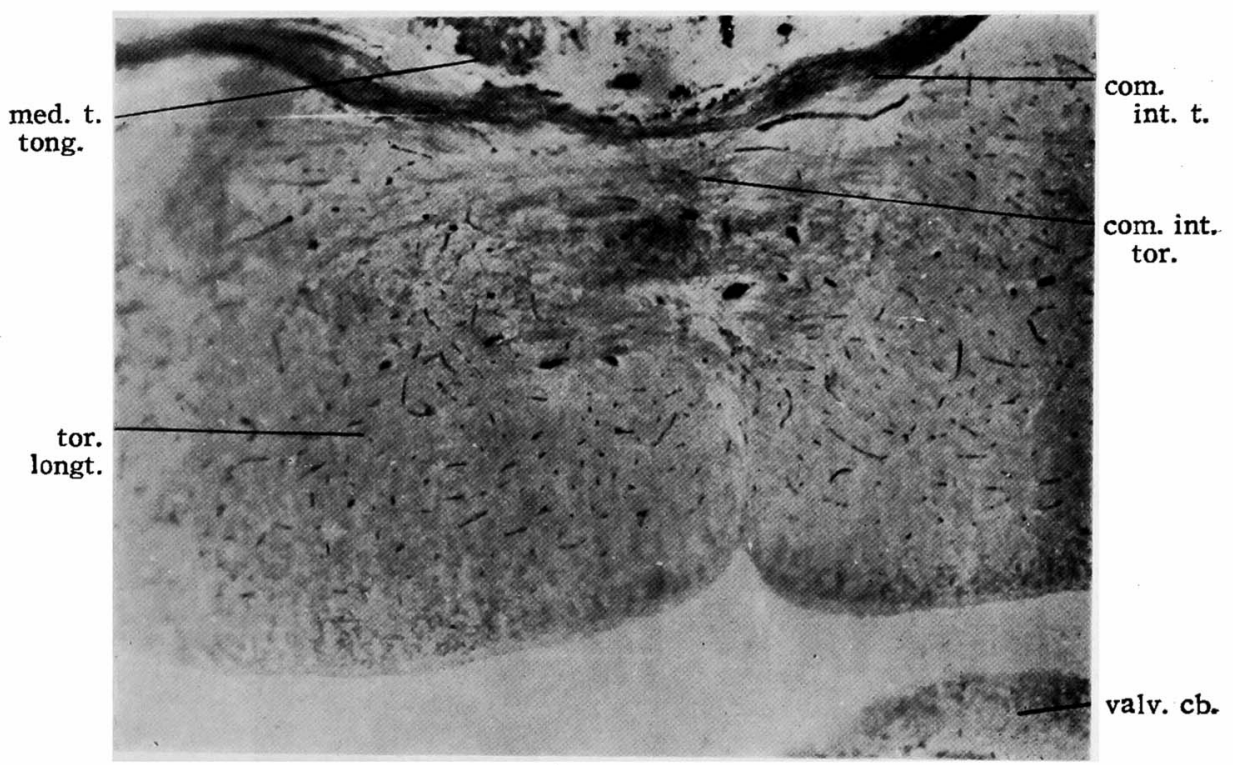

Fig. 6. Horizontal section cutting through the commissura intertectalis in the brain of Mugil cephalus.

K. Yashiki, K. Mishima, T. Hasegawa, and Y. Ikuta. 


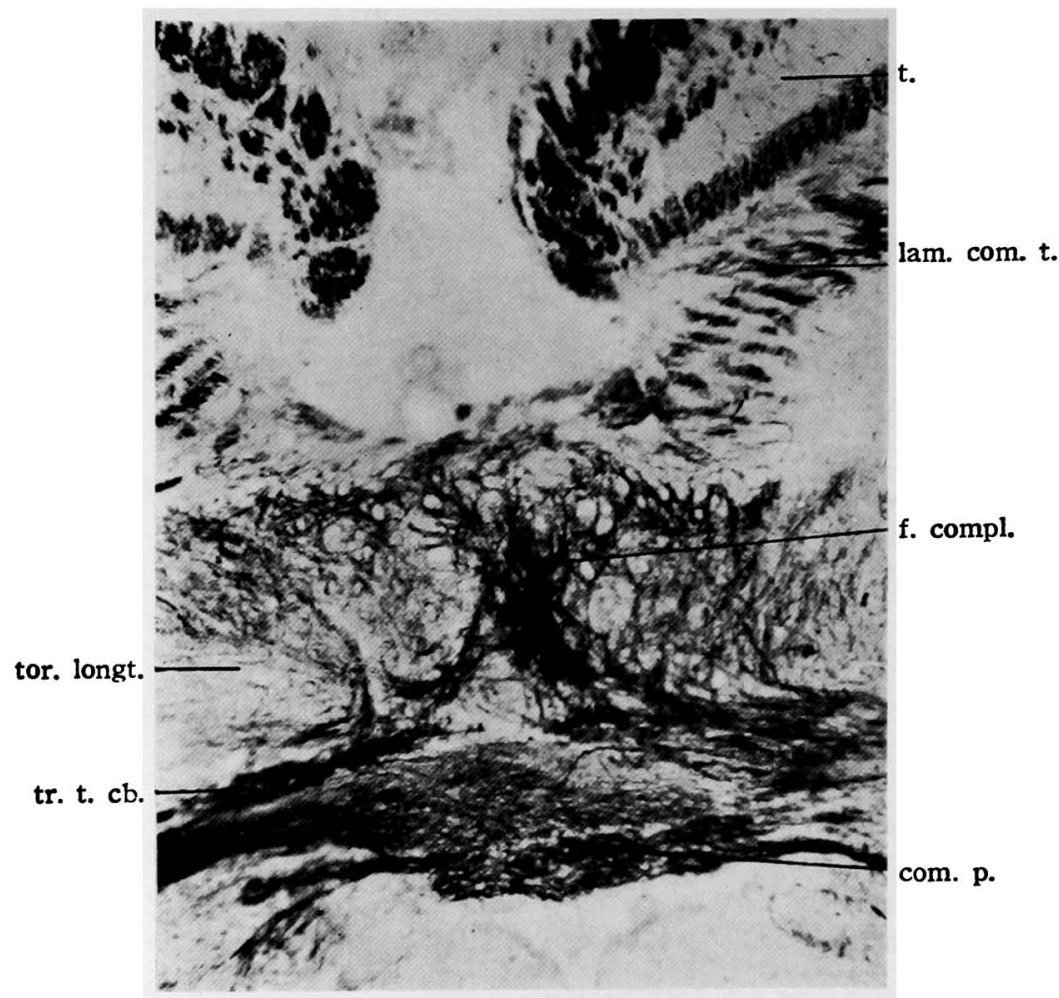

Fig. 7. Transverse section cutting through the commissura posterior in the brain of Mugil cephalus.

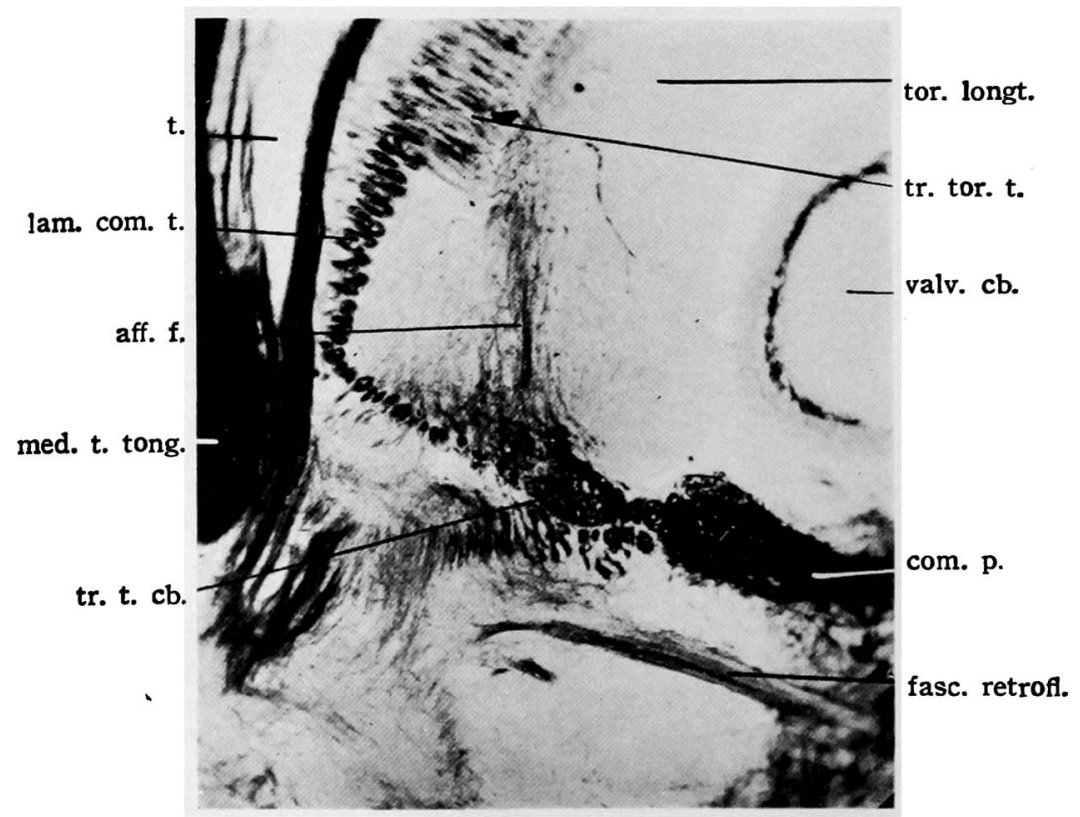

Fig. 8. Sagittal section cutting through the fasciculus retroflexus in the brain of Mugil cephalus.

K. Yashiki. K. Mishima. T. Hasegawa and Y. Ikuta. 


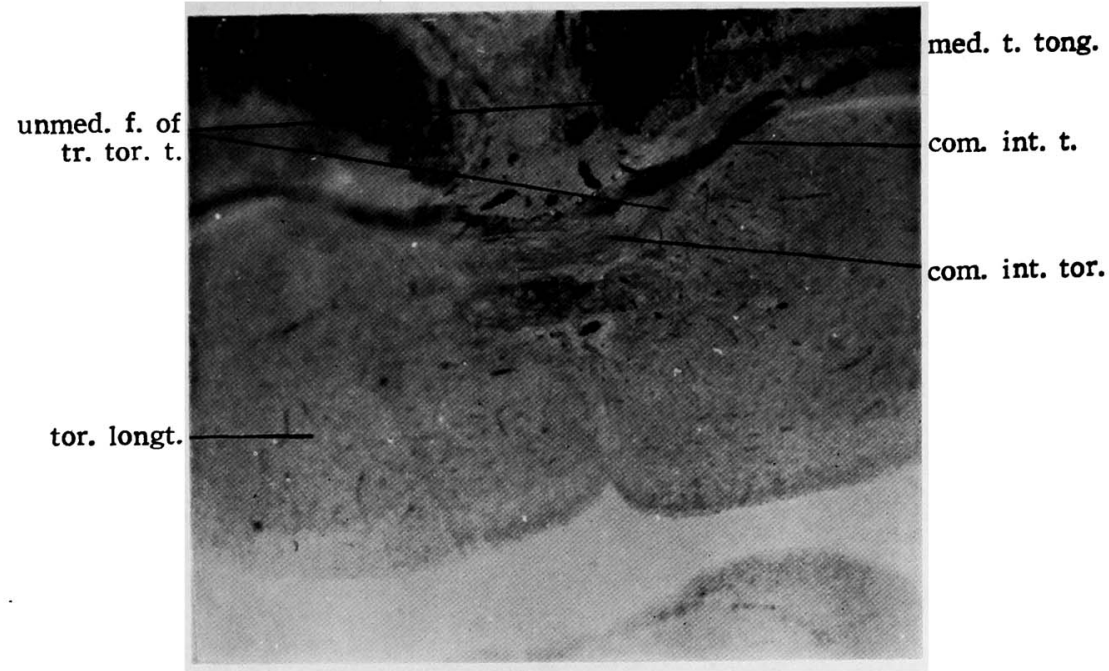

Fig. 9. Transverse section cutting through the middle segment of the torus longitudinalis in the brain of Mugil cephalus.

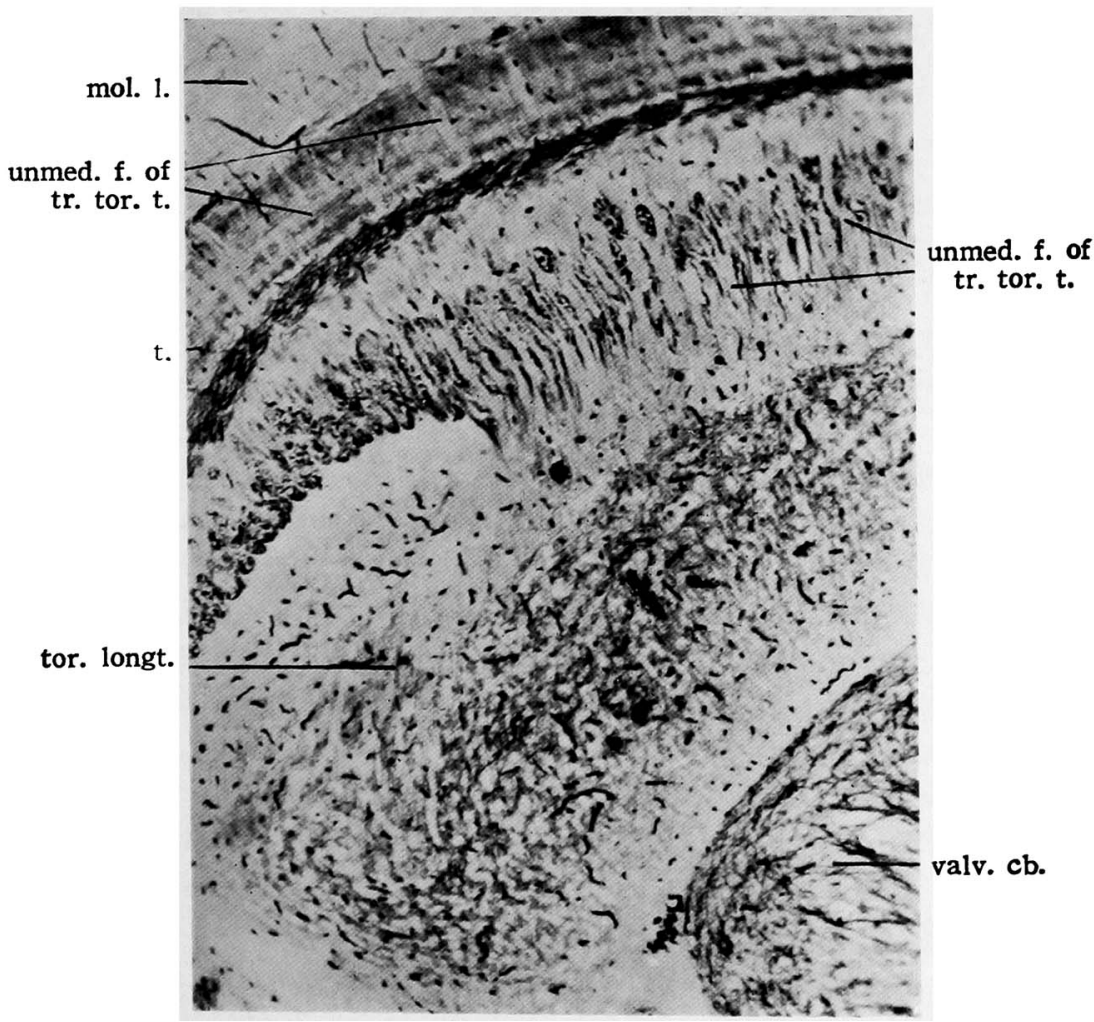

Fig. 10. Sagittal section cutting through the somewhat medial to the midline of the torus longitudinalis in the brain of Mugil cephalus (Bielschowsky's silver preparation).

K, Yashiki, K. Mishima, T. Hasegawa and Y. Ikuta 


\section{Plate VI}

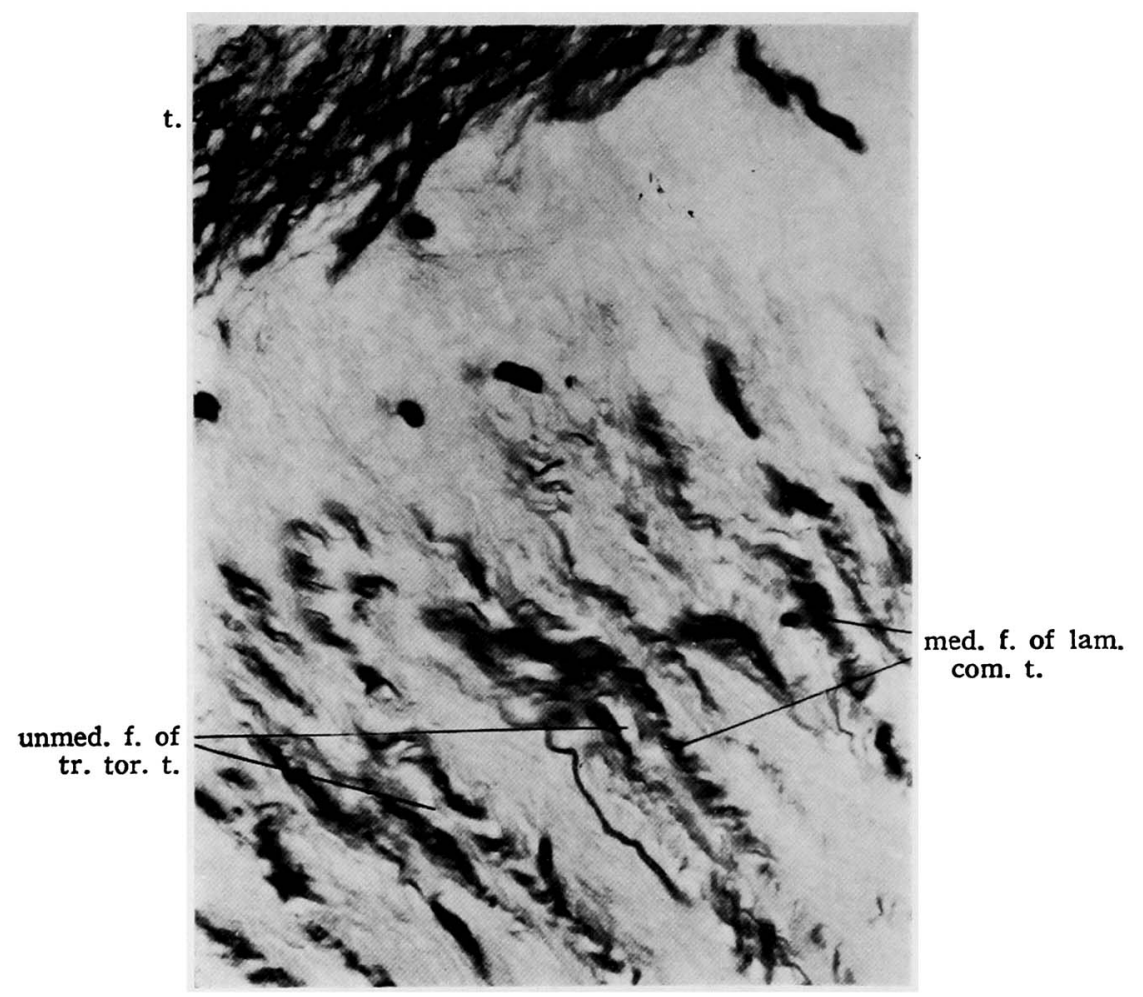

Fig. 11. Magnified photograph of Fig. 10, especially the unmedullated fibers of the tractus toro-tectalis surrounding with the medullated afferent fibers (Bielschowsky's silver preparation)

K. Yashiki, K, Mishima, T. Hasegawa and Y. Ikuta 